\title{
ROC analízis alkalmazása
}

\author{
Fazekasné Kis Mária \\ Debreceni Egyetem Agrártudományi Centrum, \\ Agrárgazdasági és Vidékfejlesztési Intézet, \\ Agrárinformatikai és Alkalmazott Matematikai Tanszék, Debrecen
}

\section{ÖSSZEFOGLALÁS}

A ROC (Receiver Operating Characteristic) analizis föként a külföldi szakirodalom szerint széles körben alkalmazott módszer a diagnosztikai tesztek hatékonyságának elemzésére. A dolgozat ismerteti a ROC analizis alapelemeit és a ROC görbe készitését, valamint bemutat néhány diagnosztikai vizsgálati eredményt reprezentáló ROC ábrát.

\section{SUMMARY}

According to publishings in foreign scientific journals, ROC (Receiver Operating Characteristic) analysis is a widely used method for analysing the diagnostic utility of clinical laboratory tests. In this paper, we explain the basic principles of ROC analysis and produce ROC curves, as well as demonstrate some ROC curves, which represent the results of diagnostic tests.

\section{BEVEZETÉS}

A diagnosztikai tesztek hatékonyságának jellemzésére többféle statisztikai módszer alkalmazható. Gyakorlatban fontos a különböző diagnosztikai tesztek hatékonyságának összehasonlítása is. A ROC (Receiver Operating Characteristic) analízis kezdeti felhasználásai az 1950-es években történtek, a radarjel észlelésével kapcsolatban. Az elmúlt évtizedben a módszer alkalmazásáról föként a nemzetközi szakirodalomban egyre gyakrabban olvashattunk (Berbaum et al., 2000; Davelaar et al., 1998; Ignjatovics et al., 2000; Linnet, 1988; Leung et al., 1989; Viitala et al., 1998; Zweig és Campbell, 1993). A módszert sokszor felhasználták a kémiai tesztek hatékonyságának elemzésére, radiológiai képfeldolgozáshoz kapcsolódóan, valamint az orvosi döntéshozatalban is (Erkel és Pattyanama, 1998; Lusted, 1960; Lusted, 1971). Viszonylag ritkán hazánkban is alkalmazták ezt az elemzési módot (Boda, 2000; Fazekasné, 1999; Fazekasné és Góth, 1999).

A ROC elemzéssel egyrészt a diagnosztikai tesztek hatékonyságáról kapunk információt, másrészt jó összehasonlításra ad alkalmat egy ábrán, ha egy betegség diagnosztizálására többféle diagnosztikai teszt eredménye is rendelkezésre áll.

A dolgozat áttekintést ad a ROC analízisről, a ROC ábra értelmezéséről, alkalmazásainak előnyeiről.

\section{ROC ANALÍZIS}

A tesztek diagnosztikai hatékonyságának méréséhez tradicionálisan a diagnosztikai szenzitivitás (érzékenység) és a diagnosztikai specificitás (specifikusság) fogalmak kapcsolódnak (Linnet, 1988; Zweigh és Campbell, 1993). A diagnosztikai hatékonyság megítéléséhez beteg és egészséges (a vizsgált betegségben nem szenvedők) csoportokban vizsgálják a teszt eredményeit, megállapítják, hogy pozitív vagy negatív. Az 1 . táblázat összefoglalja a lehetséges eseteket.

1. táblázat

A diagnosztikai tesztek eredményei

\begin{tabular}{|l|c|c|}
\hline \multirow{2}{*}{} & \multicolumn{2}{|c|}{ Teszt(1) } \\
\cline { 2 - 3 } & Negatív(2) & Pozitív(3) \\
\hline Egészségesekre(4) & $\mathrm{TN}(6)$ & $\mathrm{FP}(7)$ \\
\hline Betegekre(5) & $\mathrm{FN}(8)$ & $\mathrm{TP}(9)$ \\
\hline
\end{tabular}

Table 1: The results of diagnostic tests test(1), negative(2), positive(3), healthy(4), patients(5), true positive(6), false positive(7), false negative(8), true positive(9)

Az angol nyelvü szakirodalomban szokásos rövidítések jelentése:

$\mathrm{TP}=$ igaz pozitív (valódi pozitív teszt esetek száma)

$\mathrm{TN}=$ igaz negatív (valódi negatív teszt esetek száma)

$\mathrm{FP}=$ hamis pozitív (tévesen pozitív teszt esetek száma)

FN= hamis negatív (tévesen negatív teszt esetek száma)

„, igaz pozitív” - a teszt által helyesen betegnek minősítettek száma, ,igaz negativ" - a teszt által helyesen minősített egészségesek száma, „,hamis pozitív" - a teszt által tévesen minősített egészségesek száma, „hamis negativ” - a teszt által tévesen minősített betegek száma.

Ezek alapján:

Diagnosztikai szenzitivitás $=\mathrm{TP} /(\mathrm{TP}+\mathrm{FN})$

Diagnosztikai specificitás $=\mathrm{TN} /(\mathrm{TN}+\mathrm{FP})$

Így a diagnosztikai szenzitivitás a betegek számának arányaiból, a diagnosztikai specificitás az egészségesek számának arányaiból határozható meg.

Az ideális jó diagnosztikai teszt eredményeinek eloszlásában nincs átfedés a beteg és az egészségesek csoportjában. A diagnosztikai szenzitivitás és specificitás is $100 \%$-os. A legtöbb diagnosztikai teszt eredményeinek eloszlásában átfedést láthatunk a beteg és az egészségesek eredményei között. Alacsonyabb döntési szintet választva a hamis negatív eredmények száma csökken, de nő a hamis pozitívak száma (nagyobb a diagnosztikai szenzitivitás). Növelve a döntési szint értékét, növekszik a hamis negatív esetek száma, és csökken a hamis pozitívaké (nagyobb a diagnosztikai 
specificitás). Összefoglalva: fordított irányú kapcsolat van a diagnosztikai szenzitivitás és specificitás között.

A teszt eredmények szemléltetésére, főleg a nemzetközi szakirodalomban, alkalmazott módszer a ROC analízis. A ROC görbét egységnégyzetben ábrázolják, melynek x-tengelyén az (1-specificitás), az y-tengelyén a diagnosztikai szenzitivitás értékeket jelenítik meg. A négyzet jobboldalán feltüntethetők az (1-diagnosztikai szenzitivitás) értékek, a négyzet felső tengelyén pedig a diagnosztikai specificitás értékek is. A ROC görbe az alkalmazott teszt eredményeinek átfedését ábrázolja a betegek és az egészségesek csoportjainak adataiból, a döntési szintek teljes tartományában. A görbe minden pontja egy diagnosztikai szenzitivitás/diagnosztikai specificitás pontpárt jelenít meg egy döntési szinten. A teszt diagnosztikai hatékonysága akkor a legjobb, ha a diagnosztikai szenzitivitás és diagnosztikai specificitás is maximális, ebben az esetben a ROC görbe áthalad az egységnégyzet bal felső csúcsán. Hamis pozitív és hamis negatív eredmények ilyenkor nem adódtak, a betegek és az egészségesek eredményeit jellemző Gauss-görbék nem fedik egymást. Ha a teszt a vizsgált betegség szempontjából nem tud különbséget tenni, akkor a ROC görbe pontjai az egységnégyzet bal alsó és jobb felső csúcsát összekötő diagonális egyenes körül helyezkednek el.

A ROC görbe alkalmazható több diagnosztikai teszt összehasonlítására is, mikor ugyanazon betegség diagnosztizálására többfajta laboratóriumi teszt eredményei ismertek. Ilyenkor a különböző tesztek eredményei egy ROC ábrán jeleníthetők meg, a görbék egymáshoz és az egységnégyzetbeli elhelyezkedésük alapján hasonlíthatók össze.

A laboratóriumi teszt diagnosztikai hatékonysága kifejezhető a ROC görbe alatti terület méröszámával. A mérőszám illetve a görbe alatti terület akkor maximális (=1), mikor az alkalmazott teszt a betegek és az egészségesek teszt eredményeit „teljesen jól” megkülönbözteti. A ROC görbe alatti terület számértékét jó közelítéssel megadja a diagnosztikai szenzitivitás/diagnosztikai specificitás pont párok alatti trapézok területeinek összege. A diagnosztikai hatékonyság megítélésénél figyelembe kell venni a ROC görbék alakját is, mivel lehet két görbe alatti terület azonos, de a görbék „alakja” lényegesen eltérő.

\section{DIAGNOSZTIKAI TESZTEK EREDMÉNYEINEK ÖSSZEHASONLÍTÁSA}

A diagnosztikai tesztek eredményeinek szemléltetése történhet gyakorisági hisztogramokon. Az alábbi ábrákon gyakorisági hisztogramokon láthatóak a vér szérum kataláz enzim eredmények 229 akut szívinfarktusban beteg (1. ábra) és 111 egészséges (2. ábra) egyén csoportjaiban. A két csoport eredményeit jellemző Gauss-görbe átfedést mutat. A betegek csoportjában $80-90 \mathrm{U} / \mathrm{ml}$ értéknél van csúcs, az egészségeseknél a leggyakoribb érték $50-60 \mathrm{U} / \mathrm{ml}$.
1. ábra: A vérszérum kataláz enzim értékek a betegek csoportjában

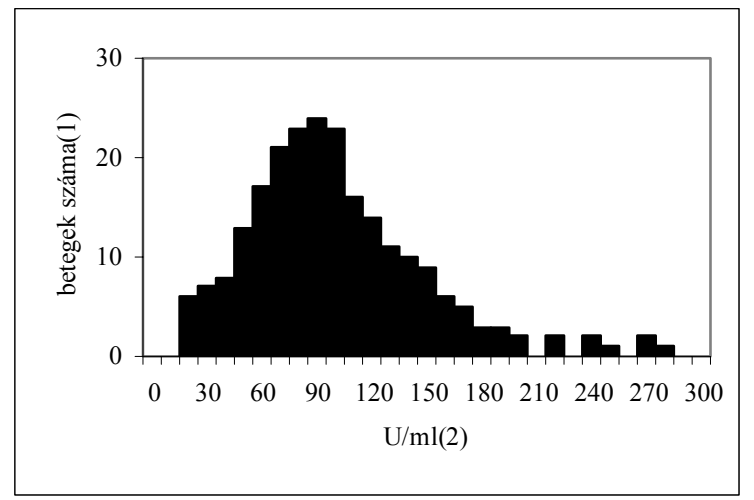

Figure 1: The value of catalase enzymes for the group of patient

number of patients(1), $\mathrm{U} / \mathrm{ml}(2)$

\section{2. ábra: A vérszérum kataláz enzim értékek az egészségesek csoportjában}

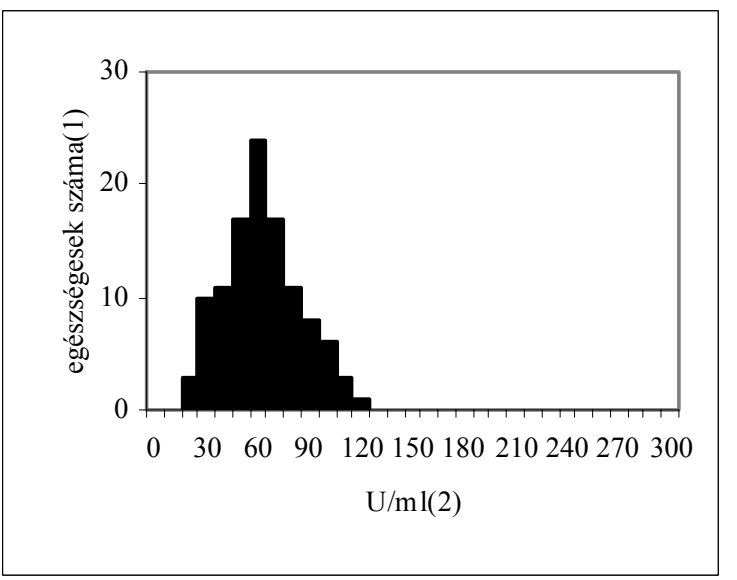

Figure 2: The value of catalase enzymes for the group of healthy

number of healthy(1), $\mathrm{U} / \mathrm{ml}(2)$

Az egészségesek vér szérum kataláz aktivitása a $(20,120) \mathrm{U} / \mathrm{ml}$ tartományba, a betegeké pedig a (20, 280) U/ml tartományba estek.

A gyakorisági hisztogramok jól mutatják az egyes mérési intervallumokban a betegek és az egészséges egyének teszt eredményeinek számát. Viszont a diagnosztikai teszt hatékonyságáról semmilyen információt nem nyújtanak.

A következő ábrák (3-4. ábra) 105 akut epehólyag gyulladásban beteg és 114 egészséges egyén csoportjaiban szintén a vér szérum kataláz enzim aktivitását mutatják. Mindkét ábrán az 50-60 $\mathrm{U} / \mathrm{ml}$ értéknél van a legnagyobb gyakoriság. Az egészségesek eredményei a $(0,130) \quad \mathrm{U} / \mathrm{ml}$ tartományba, a betegeké a $(10,330) \quad \mathrm{U} / \mathrm{ml}$ tartományba estek.

A ROC analízis alkalmazására először olyan példát mutatunk be, mikor ugyanazt a diagnosztikai tesztet (vér szérum kataláz aktivitás mérését) alkalmazzuk két különböző betegség diagnosztizálására. 
3. ábra: A vérszérum kataláz enzim aktivitás értékek akut epehólyag gyulladásban betegek csoportjában

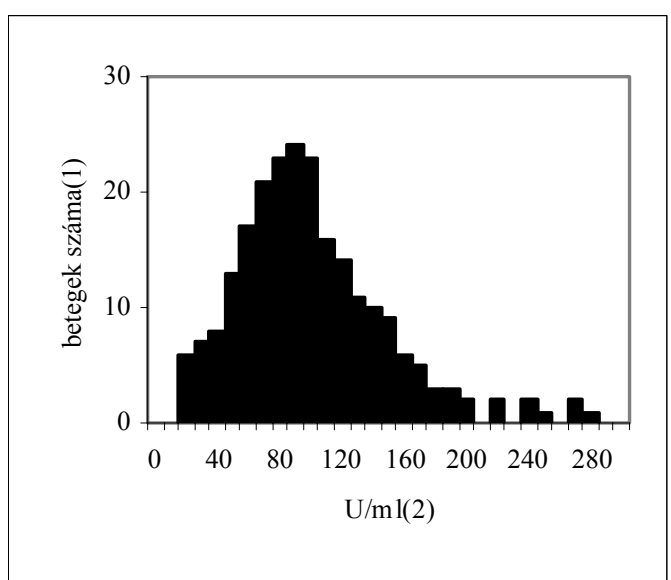

Figure 3: The activity of blood serum catalase for acute cholecystitis patients

number of patients(1), $\mathrm{U} / \mathrm{ml}(2)$

4. ábra: A vérszérum kataláz enzim aktivitás értékek akut epehólyag gyulladásban egészségesek csoportjában

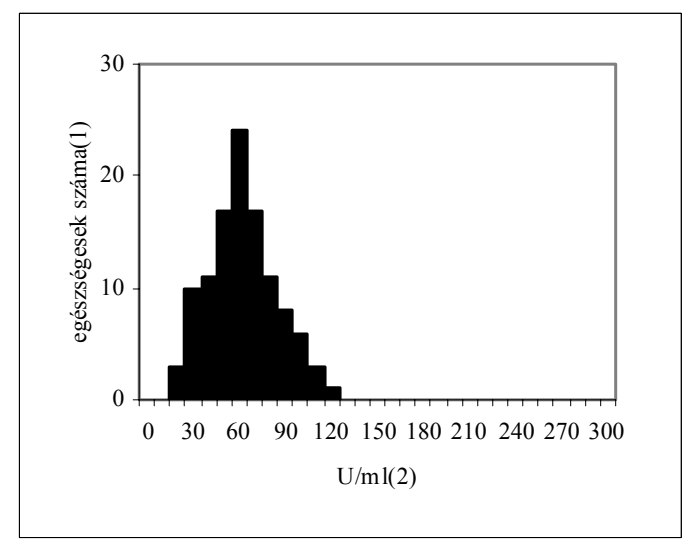

Figure 4: The activity of blood serum catalase for acute cholecystitis patients who are otherwise healthy number of healthy(1), U/ml(2)

Az előzőekben említett betegségek és számadatok alapján a ROC görbék pontjait az ismertetett módon meghatároztuk és elkészítettük a ROC ábrákat. Az 5. ábra mutatja az akut szívinfarktusban szenvedők és egészségesek csoportjainak ROC ábráját. A görbe alatti terület méröszáma megadja diagnosztikai teszt hatékonyságát, erre 0,843 érték adódott.

\section{5. ábra: ROC analízis akut szívinfarktus vizsgálatára}

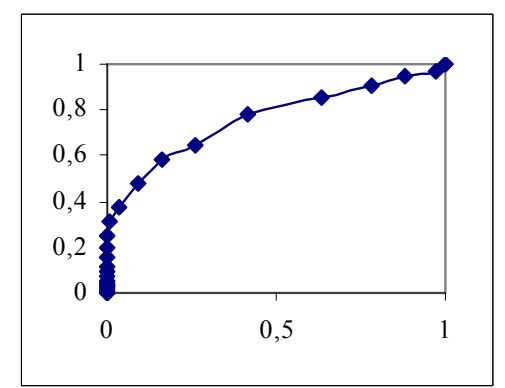

Figure 5: ROC analysis for acute myocardialis infarctus
A 6. ábrán az akut epehólyag gyulladásban betegek és ehhez képest egészségesek adataiból készült ROC görbe látható. A görbe alatti területre 0,652 értéket kaptunk, a görbe inkább az egységnégyzet diagonálisához van közelebb, mint a négyzet bal felső csúcsához. A görbe alakja alapján azt mondhatjuk, hogy alacsonyabb diagnosztikai szintnél érzékenyebb a meghatározás, mint nagyobb értékeknél. A két ROC görbe területi mérőszáma és a görbék egységnégyzetbeli elhelyezkedésük összehasonlításából arra következtethetünk, hogy a vér szérum kataláz enzim aktivitás az akut szívinfarktus diagnosztizálására nagyobb hatékonyságú, mint az akut epehólyag gyulladásra. Az utóbbi betegség gyanúját célszerü más módon is megvizsgálni.

\section{6. ábra: ROC analízis akut epehólyag gyulladás vizsgálatára}

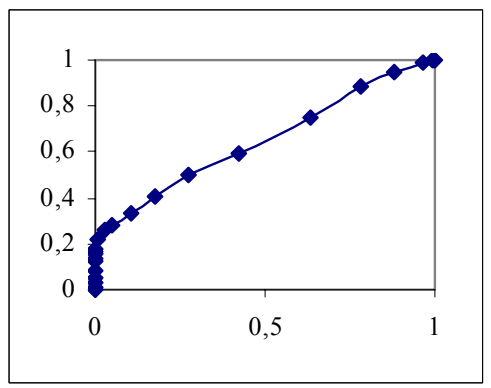

Figure 6: ROC analysis for acute cholecystitis

Klinikai laboratóriumokban a ROC analizis másik jól alkalmazható módja, mikor több különböző diagnosztikai teszt hatékonyságát hasonlítjuk össze egy betegség diagnosztizálásához. A 7. ábrán a ROC görbék az akut hasnyálmirigy gyulladás diagnosztizálásához alkalmazott lipáz és $\alpha$-amiláz tesztek eredményeit hasonlítják össze. A ROC görbék alapján is látható, hogy a lipáz enzim jobb hatékonyságú. Ezt igazolják a görbe alatti területek méröszámai is, mivel az $\alpha$-amiláz görbe alatti területe 0,5295 , ugyanez a lipáz esetében 0,9882 .

\section{7. ábra: ROC analízis akut hasnyálmirigy gyulladás esetén $\alpha$-amiláz (•) és lipáz ( ) enzimek vizsgálatával}

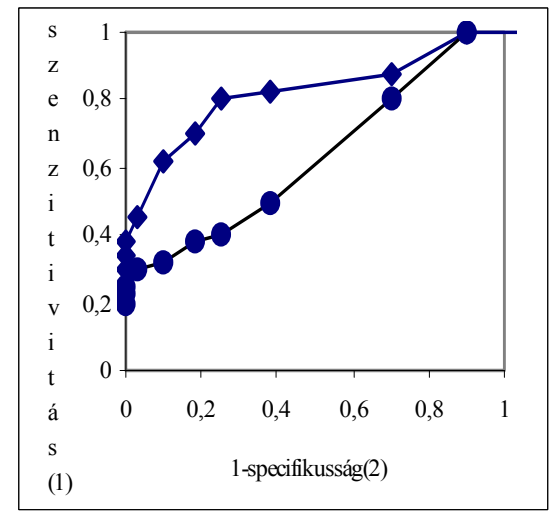

Figure 7: ROC analysis for acute pancreatitis with $\alpha$-amilase $(\bullet)$ and lipase (•) enzyme tests sensitivity(1), 1-specificity(2) 


\section{KÖVETKEZTETÉSEK}

A ROC analízis alkalmas a kiválasztott betegség diagnosztizálásához alkalmazott többféle teszt összehasonlítására, azt vizsgálva, melyiknek jobb a diagnosztikai hatékonysága. Ez a módszer a laboratóriumokban másrészt segítheti egy diagnosztikai módszer hatékonyságának megítélését többféle betegség megállapításában. A ROC görbe az elemzési eredményeket szemléletesen mutatja, a diagnosztikai teszt hatékonyságának számszerü értékét a görbe alatti terület adja, ezek alapján jól alkalmazható a döntés hozatalban.

A ROC ábra egyszerü, grafikus módon becslést ad a diagnosztikai teszt hatékonyságára. Az elemzéshez rendelkezésre álló adatok gyakoriságától független, nem szükséges, hogy a beteg és az egészséges csoport egyedeinek száma azonos legyen. Nem kell megadni egy speciális döntési szintet, mivel a ROC ábra magában foglalja a döntési szintek teljes sprektrumát. Több teszt szemléletes összehasonlítására is alkalmazható egy ábra, míg ha a hagyományos hisztogramokkal vagy vonaldiagramokkal történik a teszt eredmények prezentálása, akkor több ábrát is kell készíteni, ha a mértékegységek eltérőek. A ROC görbe készítésekor az adatok csoportosítása elmarad, szemben a hisztogramok alkalmazásával. A ROC ábra elóállításakor kapunk információt a diagnosztikai teszt szenzitivitásáról (érzékenységéről) és specificitásáról (specifikusságáról), ami nem mondható el a teszt eredmények hagyományos szemléltetési módjai esetében.

\section{IRODALOM}

Berbaum K. S.-Dorfmann D. D.-Franken E. A.-Caldwell Rt. (2000): Proper ROC analysis and joint ROC analysis of the satisfaction of search effect in chest radiology. Acad Radiol, 7. 11. 945-958.

Boda K.-Kozinszky Z.-Balogh Zs. (2000): Többváltozós regressziós modellek alkalmazása orvosi kutatási adatokra statisztikai programrendszerekkel. XXII. Neumann Kollokvium. A számítástechnika orvosi és biológiai alkalmazásai. 61-64.

Davelaar E. M.-Kamp G. J.-Verstraeten R. A. et al. (1998): Comparison of seven immunoassays for the quantification of CA 125 antigen in serum Clin Chem., 44. 1417-1422.

Erkel A. R.-Pattynama P. M. (1998): Receiver operating characteristic (ROC) analysis: Basic principles and applications in radiology. European Journal of Radiology, 27. 88-94.

Fazekasné Kis M. (1999): A ROC analízis oktatása az orvosdiagnosztikai laboratóriumi analitikus szakon. Informatika a Felsőoktatásban '99. 228-233.

Fazekasné Kis M.-Góth L. (1999): A ROC analízis alkalmazása az enzim diagnosztikában. Klin. Kísérl. Lab. Med., 26. 184-186.

Ignjatovic S.-Majkic-Singh N.-Mitrovic M.-Gvozdenovic M. (2000): Biochemical evalution of patients with acute pancreatitis. Clin Chem., Lab Med., 38. 11. 1141-1144.
Kazmierczak S. C.-Lente F.-Hodges E. D. (1991): Diagnostic and prognostic utility of phospholipase. A activity in patients with acute pancreatitis: comparison with amylase and lipase. Clin Chem., 37. 3. 356-360.

Keim V.-Teich N.-Reich A.-Fiedler F.-Mössener J. (1997): Polyclonal pancreatic elastase assay is superior to monoclonal assay for diagnosis of acute pancreatitis. Clin Chem., 43. 12. 2339-2344.

Leung F. Y.-Galbralth L. V.-Jablonsky G. et al. (1989): Reevalution of the diagnostic utility of serum total creatine kinase and chreatine kinase-2 in myocardial infarction. Clin Chem., 35. 1435-1440.

Linnet K. (1988): A review on the methodology for assessing diagnostic tests. Clin. Chem., 34. 7. 1379-1386.

Lusted L. B. (1960): Logical analysis in roentgen diagnosis. Radiology, 74. 178-193.

Lusted L. B. (1971): Signal detectability and medical decision making. Science, 171. 1217-1219.

Viitala K.-Landesmaki K.-Niemela O. (1998): Comparison of the axis \%CDT TIA and CDTect method as laboratory tests of alcohol abuse. Clin Chem., 44. 1209-1215.

Zweig M.-Campbell G. (1993): Receiver-Operating characteristic (ROC) plots: a fundamental evaluation tool in clinical medicine. Clin. Chem., 39. 4. 561-577. 